\title{
О ФОНЕТИЧЕСКИХ ТРУДНОСТЯХ ПРИ ОБУЧЕНИИ РКИ: ИЗ ОПЫТА РАБОТЫ
}

\author{
ТАТЬЯНА В. ЧЕРКЕС \\ Гродненский государственный университет имени Янки Купалы \\ Кафедра языковой подготовки белорусских и иностранных граждан \\ ул. Элизы Ожешко, 22, 230023, г. Гродно, Республика Беларусь \\ e-mail: t_koteleva@mail.ru \\ ORCID: https://orcid.org/0000-0001-7853-879X \\ МАЛГОЖАТА МАРЦИШЕВСКА \\ Uniwersytet Gdański \\ Wydział Filologiczny, Instytut Rusycystyki i Studiów Wschodnich \\ Katedra Pragmatyki Komunikacji i Akwizycji Języka \\ Neofilologia, ul. Wita Stwosza 51, 80-308 Gdańsk, Polska \\ e-mail: filmm@ug.edu.pl \\ ORCID: https://orcid.org/0000-0002-6050-2112 \\ (получено 27.07.2018; принято 11.09.2018)
}

\section{Abstract \\ On phonetic difficulties in the teaching of RFL: from work experience}

This article is devoted to the presentation of the most common phonetic problems arising in the teaching of RFL in monolingual (Polish speaking) and polylingual groups. Characteristic difficulties in pronunciation among Poles caused by the interaction of two similar language systems (Polish and Russian) are described. The most frequent phonetic problems encountered in polylingual groups are identified. Proposed methods and ways of working on the most common mistakes contribute to the correction of the pronunciation of university students. Developed variants of exercises contribute to the gradual elimination of phonetic problems. This didactic material can be used at 
the initial stage of the RFL teaching and it also can be useful both during the teaching of RFL at an advanced level, and during short-term language courses. The relevance of the paper lies in the fact that it offers some recommendations that have proved effective in the process of correcting the difficulties in pronunciation at the initial stage of teaching Russian as a foreign language. The assignments are of an applied nature and are approved by the authors as a result of joint international exchange at the universities of Belarus and Poland.

\section{Key words}

Russian as a foreign language, the initial stage, difficulties in the teaching of pronunciation, monolingual and polylingual groups.

\section{Резюме}

Актуальность исследования заключается в том, что в нем предлагаются некоторые рекомендации, которые доказали свою эффективность в процессе коррекции трудностей произношения на начальном этапе обучения русскому языку как иностранному. Задания носят прикладной характер и апробированы авторами в результате совместной международной стажировки в вузах Беларуси и Польши. Данная статья посвящена презентации наиболее распространенных трудностей русской фонетики, возникающих при обучении РКИ в монолингвальных (польскоязычных) и полилингвальных группах. Описываются характерные трудности в произношении, которые в результате взаимодействия двух родственных языков приводят к интерференции у поляков; выявляются наиболее частые фонетические проблемы, встречающиеся в полиязычных группах. Предлагаемые методы работы над наиболее распространенными ошибками содействуют коррекции произношения универсантов, разработанные варианты заданий способствуют постепенному устранению фонетических проблем. Дидактический материал статьи может использоваться на начальном этапе обучения РКИ, а также быть полезным как во время преподавания РКИ на продвинутом этапе, так и на краткосрочных языковых курсах.

\section{Ключевые слова}

Русский язык как иностранный, начальный этап обучения, трудности в обучении русской фонетике, монолигвальные и полилигвальные группы.

В процессе реализации современной поликультурной образовательной парадигмы одним из приоритетных направлений в преподавании дисциплин (в том числе русского языка как иностранного - далее РКИ) является профессиональная академическая мобильность и непрерывное повышение педагогического мастерства. Как известно, болонская модель, целью которой является 
создание единого общеевропейского образовательного пространства, предполагает развитие интеграции в сфере высшего образования для обмена академическими ценностями.

В рамках международного договора о сотрудничестве между кафедрой прагматики коммуникации и лингводидактики Гданьского университета (Республика Польша) и кафедрой языковой подготовки белорусских и иностранных граждан Гродненского государственного университета имени Янки Купалы (Республика Беларусь) для обмена опытом и повышения профессиональной подготовки была реализована программа двусторонней академической мобильности. Она была осуществлена в форме двухмесячной стажировки, которая включала в себя научно-методический аспект (участие с выступлениями на конференциях и семинарах), дидактическую составляющую (посещение лекций, мастер-классов и практических занятий), а также прикладную часть (работа в качестве преподавателя в группах принимающего университета). Актуальность исследования состоит в том, что в описании проблем присутствует «свежий взгляд»: один из авторов статьи до стажировки работал только в национальных группах вне языковой среды по методике с использованием языка-посредника (преподавание РКИ в Польше). Другой исследователь имел опыт работы в моно- и в полиязычных группах, находящихся в языковой среде страны, где изучаемый язык имеет статус государственного (Беларусь). В процессе обучения применялись методы и технологии преподавания РКИ без использования языка-посредника.

Данная работа посвящена анализу трудностей русской фонетики, возникающих в моноязычных и полиязычных группах на начальном этапе обучения РКИ. Предлагаемые тренировочные упражнения направлены на коррекцию и постепенное устранение трудностей произношения.

С нашей точки зрения, выбор последовательности и презентация фонетического материала в польских учебниках по РКИ основан с учетом сравнительно-аналитического и сопоставительного методов, согласно которым учитываются лингвистические явления родного языка учащихся. Учебники такого типа в методике РКИ называются национально-ориентированными. В них, согласно мнению Капитоновой, Московкина, «ученые устанавливают сходства и различия фонетических явлений русского языка и родного языка учащихся (...). Затем фонетический материал располагается по степени возрастания трудностей» (Капитонова, Московкин, 2006, с. 111). В Беларуси при обучении РКИ используются учебники так называемого общего типа, поскольку на факультетах довузовской подготовки изучают язык универсанты из стран Европы, Азии, Африки и Америки. Так, в исследуемой группе, в которой проводились занятия в рамках стажировки, обучались студенты из Китая, Ирака, Конго, Нигерии и Ганы. Учебники общего типа составлены с учетом трудностей системы изучаемого языка и построены согласно принципу: от простых лингвистических явлений изучаемого языка к более сложным. Следовательно, на начальном этапе обучения РКИ «материал (...) вводится в зависимости от особенностей русской фонетической системы» (Сашина, 2016, с. 2). Различаются также учебные программы и планы высших учебных заведений Польши и Беларуси. Так, на изучение алфавита и фонетических трудностей русского языка в польских университетах 
отводится 15 академических часов (здесь и далее мы говорим о практическом курсе РКИ, так как для филологов-русистов существует отдельная дисциплина «Фонетика русского языка»). Тогда как в Беларуси пропедевтический курс составляет 80-90 часов (в зависимости от национального состава группы, от уровня их успеваемости, индивидуальных особенностей и т.д.). Однако известно, что для успешной речевой деятельности обучающимся требуется постоянная коррекция фонетических ошибок и трудностей. В методической литературе такой курс получил название сопроводительного: обычно преподаватель РКИ при проведении практического занятия ежеурочно уделяет 10-15 минут фонетической зарядке, поскольку «становление навыков приемлемого иноязычного произношения при регулярных занятиях языком обычно занимает не менее двух лет» (Капитонова, Московкин, 2006, с. 110).

Общеизвестно, что в процессе обучения РКИ как в монолингвальной, так и полилингвальной группах существуют определенные преимущества и недостатки. Положительные и отрицательные аспекты процесса восприятия и воспроизведения фонетических явлений изучаемого (русского) языка отражены в таблице 1 (в монолингвальной группе) и таблице 2 (в полилингвальной группе).

Таблица 1. Монолингвальная группа

\begin{tabular}{|c|c|}
\hline Преимущества & Недостатки \\
\hline $\begin{array}{l}\text { • наличие общих для универсантов фоне- } \\
\text { тических трудностей представляет боль- } \\
\text { шой потенциал для системной работы по } \\
\text { устранению определенных трудностей } \\
\text { произношения; } \\
\text { • «общность родного языка, фоновых зна- } \\
\text { ний, <...> психологии речевой деятель- } \\
\text { ности» открывает широкие возможности } \\
\text { для использования сопоставительного } \\
\text { метода (посредством сравнения фонети- } \\
\text { ческих явлений родного и русского языка). }\end{array}$ & $\begin{array}{l}\text { - отсутствие речевой практики вне аудито- } \\
\text { рии (общение между универсантами на } \\
\text { родном языке); } \\
\text { - «сниженная» мотивация (преобладает } \\
\text { подсознательное / осознанное ожидание } \\
\text { перевода). }\end{array}$ \\
\hline
\end{tabular}

* Источник: Музыченко, 2014, с. 125.

Как известно, «обучение произношению русской речи включает артикуляцию звуков, ударение, ритмику, интонацию и в конечном итоге предполагает овладение фонетической системой русского языка в практических целях» (Любимова, 1982, с. 3-4). Мы остановимся, в основном, на артикуляционных трудностях, поскольку такие аспекты, как ударение, ритмика и интонация требуют отдельного рассмотрения.

При формировании произносительных навыков Пассовым выделяются следующие стадии:

1. Восприятие-ознакомление (в процессе которого учащиеся знакомятся с практическим аспектом фонетического явления, в результате чего в про- 
Таблица 2. Полилингвальная группа

\begin{tabular}{|c|c|}
\hline $\begin{array}{l}\text { Преимущества } \\
\text { • повышение мотивации для общения на } \\
\text { изучаемом языке (нет общего языка-по- } \\
\text { средника, что создает естественные пред- } \\
\text { посылки для снятия «языкового барьера»); } \\
\text { • наличие условий для постоянного обще- } \\
\text { ния на русском языке во внеурочное время } \\
\text { в языковой среде (ускоряются процессы } \\
\text { преодоления трудностей психологическо- } \\
\text { го характера); } \\
\text { - речевое общение с носителями языка, } \\
\text { имитация звучащей речи (способствуют } \\
\text { естественному процессу коррекции труд- } \\
\text { ностей произношения). }\end{array}$ & $\begin{array}{l}\text { Недостатки } \\
\text { - национально обусловленная (а иногда } \\
\text { и личностно обусловленная) «разрознен- } \\
\text { ность» трудностей произношения универ- } \\
\text { сантов усложняет работу, направленную } \\
\text { на системную коррекцию фонетических } \\
\text { ошибок и актуализирует потребность } \\
\text { в индивидуальном подходе. }\end{array}$ \\
\hline
\end{tabular}

цессе презентации данного произносительного явления создается его звуковой /слуховой образ).

2. Имитация (закрепляются связи слуховых и речедвигательных образов единицы речи).

3. Дифференцировка-осмысление (происходит понимание признаков звуковых различий, формирование артикулирования, отрабатывается воспроизведение фонетической единицы).

4. Изолированная репродукция (закрепление прагматического значения изучаемой единицы в речевой практике).

5. Комбинирование / переключение (комплексное использование произносительных явлений. Целенаправленное переключение внимания с одного фонетического явления на другое для выработки произносительного навыка) (Пассов, 1989, с. 163-165).

Рассмотрим характерные трудности произношения, которые наиболее часто встречаются в моно- и полилингвальных группах. При описании фонетических явлений нами использовался принцип их дифференциации согласно родному языку универсантов, поскольку, «(...) фонологическая система любого языка является как бы ситом, через которое просеивается все сказанное» (Трубецкой, 1960 , с. 59). Обратимся к проблемам произношения монолингвальной (польскоязычной) аудитории. Во время первого года обучения у польских студентов, начинающих изучать русский язык, возникает ряд фонетических трудностей, связанных, с одной стороны, с различиями, с другой - со схожестью фонетических систем польского и русского языков. К различиям относятся семиотические особенности польского и русского алфавитов, специфика фонемного состава языков, дифференцированные нормы позиционной реализации фонем, их взаимосвязь, особенности интонационных конструкций, свойства русского ударения, трудности в произношении определенных звуков. К примеру, Анхимюк выделяет «произношение [ł] вместо [л], [szcz] вместо [щ], [cz] вместо [ч], рья вместо ря, лья вместо ля, тья вместо 
учета редукции» (Anchimiuk, 2015, с. 2). Следует отметить трудности произношения вышеуказанных звуков, возникающие из-за их различных кинемных свойств (наличия / отсутствия палатализации): например, в польском языке сочетания [szcz], [cz] произносятся твердо, тогда как в русском языке [ш'т'ш'], [т'ш'] - мягкие согласные (здесь и далее нами используется фонетическая

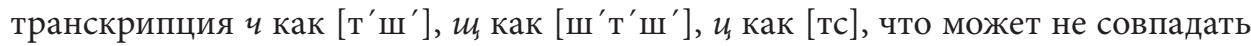
с обозначениями данных звуков в цитируемых источниках). При обучении произношению русских звуков [л], [л'] необходимо обратить внимание на отличие способа образования звука [ł] от фонем [л], [л']: польский [ł] является лабилизованным, тогда как [л], [л'] - язычно-альвеолярными. В практическом курсе РКИ нами были выделены также замена аффрикат: звука [т'ш'] звуком [тс] (соответствующим польскому [c]): тысяча - mыся $[m c] a$, ночь - но[mc]. Чтобы нивелировать данные произносительные трудности, Битехтина, Климова рекомендуют обратить внимание обучающихся на правильную артикуляцию звука [тс], начальным этапом которой «является образование дорсальной смычки: передняя часть языка прижимается к альвеолам, кончик языка опущен к нижним зубам» (Битехтина, Климова, 2011, с. 40). Имело место также «позвуковое» чтение и произношение возвратных глаголов: $\left[m^{\prime} c^{\prime} a\right]$ вместо [mc:a]: смеётся

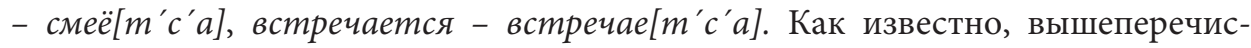
ленные трудности произношения ведут к появлению ошибок, интерференции. Согласно определению авторов Лингвистического энииклопедического словаря, интерференция представляет «взаимодействие языковых систем в условиях двуязычия», которое «выражается в отклонениях от нормы и системы второго языка под влиянием родного». Вследствие такого отрицательного взаимовлияния подобных по фонемному составу лингвистических систем, как указывается Касько, появляются условия, которые способствуют «возникновению устойчивых черт акцента. Кажущееся сходство может быть более опасно, чем яркое различие. Так, в произношении поляков все русские гласные сдвинуты вперед, и устранить эту произносительную черту крайне сложно в силу сходства фонемного состава русского и польского языков» (Касько, 2000, с. 129). В качестве примеров, в которых похожие по звучанию слова «автоматически» произносились по-польски, можно привести числительные четыре - [čtery], nяmь [p'i ė́ń́c, восемь - [ośẽm] и т.д.

Фонетические трудности полиязычной группы будут рассматриваться на основе произносительных трудностей китайских, арабоговорящих, франкои англоговорящих универсантов. Рассмотрим проблемы произношения, характерные для студентов из Китая. Поскольку китайский язык является одним из вокальных языков, а русский принадлежит к числу консонантных, различия фонетических систем способствуют интерференции. Известно, в китайской фонетической системе существует определенный слоговой порядок в слове: 1) согласные; 2) гласные. Отсюда следует отсутствие закрытых слогов и невозможность нахождения двух и более согласных рядом внутри слога. По мнению Ереминой и Еремина, при работе в китайской аудитории к интерференции можно отнести «явление эпентезы, когда студенты вставляют для облегчения произношения гласные звуки между согласными» (Еремина, Еремин, с. 11). 
Примеры эпентезы: завтрак - за́[былы mо́бус и т.д. Исследователи отмечают такое интерференционное явление, как диереза, «когда не произносится один из согласных» (Еремина, Еремин, с. 13). В качестве примеров диерезы приведем такие: шумно - wý[_н]о, воскресныц вос[_p]е́сный, немного - не[_н]ого.

Следующую фонетическую проблему у китайских студентов представляет произношение звонких согласных [б], [г], [3], [д] (замена при говорении и в процессе письма их глухими согласными [п], [к], [с], [т]). По мнению Цзинь и Пановой, «китайцы (...) не слышат разницы между звонкими и глухими русскими согласными, так как не могут определить, есть или нет колебание голосовых связок» (Цзинь, Панова, 2015, с. 8). Это приводит в русской речи китайских студентов к таким ошибкам в произношении: банк - [na]нк, гости - [ко']cmu, здоров - $[$ ста]ров, дедушка - [m 'э́m $]$ ушка и др. К трудностям произношения можно отнести также отсутствие в китайском языке мягкого [т'ш']: «китайский согласный звук $[\mathrm{ch}]$ всегда твёрдый и является придыхательным. Такое различие звуков приводит к фонетической интерференции» (Цзинь, Панова, 2015, с. 5). К примеру: четыре - [chьl]mы'ре, чудесный - [chy]де́сный, часто - [chá']cmо и пр.

Кроме того, интерференцию вызывает и отсутствие в китайском языке шипящих [ш], [ш'т'ш']. Как правило, учащиеся пытаются заменить их в процессе говорения звуком [c]: шёл - [сол], шеётка - [c'ómка] и т. д.

Следует отметить, что особую трудность для китайских студентов представляет произношение сонорного [р], поскольку в китайском языке этот звук отсутствует. На начальном этапе китайцы часто произносят вместо [р] звук [л], что ведет как к коммуникационным неудачам, так и к ошибкам в письменной речи: рада -[ла']да, pom-[ло]m, рыжей -[ль'] жей и пр. Как отмечают исследователи, «постановка данного звука в китайской аудитории представляет достаточно сложную задачу, требует значительных усилий и времени» (Андреюшина, 2014, c. 21).

От характерных фонетических ошибок, допускаемых китайскими студентами, перейдем к особенностям произношения в арабской аудитории. В связи с отсутствием в арабском языке звуков [о], [э], [ы], по словам Ибрагимовой и Светловой, «арабоязычные студенты не всегда способны четко дифференцировать фонемы [о] и [у], [и] и [јэ]» (Ибрагимова, Светлова, 2016, с. 492), например: $c[o] \kappa-c[y] \kappa$; «перед согласными звук [и] арабы приближают к звуку [э] или [о]» (Ибрагимова, Светлова, 2016, с. 492) и произносят [э]гра вместо игра, [э] грушка вместо игрушка. «Звук [ы] (...) требует постановки и автоматического закрепления новой артикуляции» (Ибрагимова, Светлова, 2016, с. 492), так как вызывает большую трудность у арабоязычных учащихся.

Вслед за Валеевой и Шарафутдиновой, отметим следующие наиболее распространенные интерференционные явления, к которым относятся:

- «произношение арабского [b] на месте русских [б] и [п]» (Валеева, Шарафутдинова, 2017, с. 137): правильно - [b]ра́вильно, приехал - [b]рие́хал, брат - [b]pam и пр.;

- замена русского звонкого согласного [в] арабским [f]: вот - [f]om, ваза - [f] аз $а$; 
- «последовательное произношение удвоенных согласных в русских словах, где они чаще всего не произносятся» (Валеева, Шарафутдинова, 2017, с. 137): длинныци - дли'[н]ьй, ванна - ва́[н]a;

- «недостаточная количественная редукция гласных или слишком сильная редукция гласных вплоть до их выпадения: пожалуйста - пожал[i]ста» (Валеева, Шарафутдинова, 2017, с. 137).

Обратимся к рассмотрению трудностей произношения, характерных для франкоговорящих студентов. По утверждению Пархоменко, наиболее типичными являются:

- «артикуляция звука [ы], соответствия которому нет в их родном языке» (Пархоменко, 2016, с. 34). Что служит причиной замены данного звука в процессе коммуникации звуком $[и]: c[b l] p-c[u] p$;

- отсутствие слухопроизносительного навыка в дифференциации и «произношении мягких и твердых согласных» (Пархоменко, 2016, с. 35): вес - весь;

- при произношении переднеязычных [р] и [р'] носители французского языка заменяют их на увулярный [r];

- «переднеязычные зубные [л] и [л'] (...) заменяются т. н. европейским» (Пархоменко, 2016, с. 35) (сонорными среднеязычными во французском, сербском языках) (Битехтина, Климова, 2011, с. 12);

- «трудности вызывает и произношение звука [ш’:], а также его дифференциация со звуками [ш] и [ч’]» (Битехтина, Климова, 2011, с. 12).

Следующей исследуемой группой являются англоговорящие студенты. Как отмечает Андреюшина, «большинство русских звуков имеют приближенные аналоги у представителей романо-германских языков. Но разница заключается в качестве их произношения» (Андреюшина, 2014, с. 20), например звук [а] произносится по-другому. По словам Федяниной, «увеличение длительности русских ударных гласных в произношении англоговорящих влечет за собой их дифтонгизацию, так как долгие гласные в английском языке (...) дифтонгизируются. Недопустимо также произношение русских гласных под ударением по нормам произношения английских сверхкратких ударных гласных, являющихся гласными неполного образования» (Федянина, 1979, с. 31).

Как пишет Андреюшина, «английская (...) речь лабиализована менее русской. В русской речи при произнесении гласных огубление является нормой. Английский (...) вокализм (...) ориентирован на звуки, произносимые с растягиванием губ» (Андреюшина, 2014, с. 20), поэтому в англоговорящей аудитории возникают отклонения в произношении гласных [о], [и], [y].

Звук [ы] вызывает особые трудности в произношении, так как в английском языке нет соответствующего эквивалента. Учащиеся часто смешивают этот звук с [и] или [э].

Что касается различения согласных по твердости - мягкости, то в английском языке, по словам Федяниной, «фонематическое противопоставление согласных по твердости - мягкости отсутствует. Английские согласные могут быть несколько смягченными, частично палатализованными перед гласными переднего ряда. Но это различие не является фонологическим» (Федянина, 1979, c. 27). Это явление в сочетании с определенными гласными приводит к ошибкам 
при произнесении, в частности, согласных [л] и [л'], гласных [е], [ё], [ю], [я], обозначающих мягкость предыдущего согласного.

Итак, несмотря на то, что в каждой из исследуемых языковых групп (в польскоговорящей, в китайско-, в арабоговорящей и т.д.) существуют «свои» фонологические проблемы, многие трудности универсальны (например, дифференциация согласных по твердости - мягкости, глухости - звонкости, произношение шипящих и свистящих, сонорных, отклонения в произнесении гласных и т.д.). Предлагаемые дидактические материалы направлены на системную коррекцию и устранение наиболее часто встречающихся фонетических ошибок.

Как неоднократно отмечалось выше, в процессе работы в монолингвальной и в полилингвальной группах важную роль играет выработка слухопроизносительных навыков. Как отмечается Акишиной и Каган, «различение звуков вначале вырабатывается на уровне аудирования, а затем переносится на произношение. Рекомендуется постоянно проводить диктанты на аудирование» (Акишина, Каган, 1997, с. 197). Вначале студентам предлагаются: 1) слоговые, незначительно отличаются друг от друга пары; 2) односложные, двух-, трехсложные слова / звукосочетания; 3) предложения.

Например, с учетом произносительных трудностей в польской аудитории для выработки навыков аудирования рекомендуется проводить подобные виды диктантов (диктанты направлены на коррекцию наиболее сложных для аудирования и произношения звуков: [л] и [л'], [ш'т'ш', [т'ш'], [тс]): 1) ла-ля, ли-

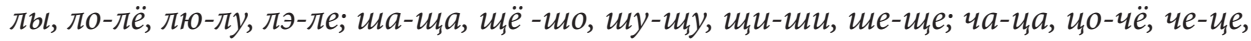
иу-чу, чи-иьь. 2) Лак-ляг, лик-льк, лом-лём, лук-люк, лев-лэв; шар-щар, шёк-иок,

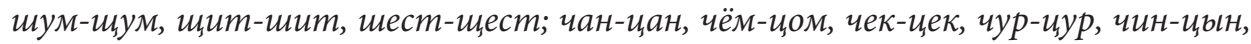
ияаца-чача... 3) Ляля около рояля. Лола около виоль. Лиля любит Лёлика. Щенку шепчу на ушко я стишок. Щёткой чистить шерсть щекотно. В чернильнице часто кончаются чернила. Чайки кричали целую ночь. Чёрная изапля иапнула цыпленка.

В полинациональной группе рекомендуется использовать диктанты, при которых звуковые пары различаются по звонкости - глухости, мягкости - твердости, а также на «проблемные» гласные и сонорные звуки: 1) ба-па, пя-бя, бо-по, бё-пё, пу-бу, бю-пю, пэ-бэ, бе-пе, пь-бы, би-пи; ва-ба, во-бо, ву-бу, вьь-би, вэ-бэ, раря, ро-рё, ру-рю, рэ-ре, рь-ри...; ра-ла, ло-ро, лу-ру...; ша-ча, шо-чё, шу-чу, ше-че, чи-чи и т.д. 2) бам-пам, пят-бят, бот-пот, воз-вёз, бён-пён, пух-бух, бют-пют, пэр-бэр, бес-пес, виза-вызов, ... 3) Бабушка Вове варила борш.. Папа в баре с Варей в паре. Саша учится читать и считать. В роще и чаще дышится слаще. На ралли «Роллс-Ройс» угнали.

Результативны на этапах введения и отработки нового фонетического материала фонетические упражнения. Обычно при выборе упражнений, направленных на нивелирование трудностей произношения, учитывается изучаемый лексико-грамматический материал. Как известно, фонетические упражнения делятся на языковые (тренировочные) и речевые (коммуникативные). Согласно Методике преподавания русского языка как иностранного на начальном этапе, «языковые упражнения включают в себя отработку произношения и чтения 
слогов, знакомых и незнакомых слов, словосочетаний, коротких текстов, диалогических единств» (Дергачева, 1983, с. 27).

Приведем примеры языковых фонетических заданий, которые проводятся как в моно-, так и в полилингвальной группах с различным наполнением (используется актуальный для изучаемого этапа фонетический материал):

1) Слушайте;

2) Слушайте и повторяйте про себя;

3) Слушайте и опознавайте данный звук;

4) Слушайте и повторяйте во время пауз;

5) Слушайте и повторяйте вместе с диктором (преподавателем);

6) Слушайте, повторяйте, читайте.

7) Слушайте. Пишите, расставьте ударения.

8) Читайте и записывайте свое произношение на диктофон и др. (Акишина, Каган, 1997, с. 202-203)

Другой вид фонетических упражнений - речевые (коммуникативные) упражнения. Они «направлены на снятие трудностей, аналогичных естественному речевому общению, и предполагают реализацию выработанных навыков в речи» (Власова, 1990, с. 82). Речевые упражнения с коммуникативной установкой рекомендуются на этапе, завершающем изучение фонетического явления. Примеры подобных заданий:

1) Спросите у Вашего друга, ...;

2) Ответьте на вопрос товарища о ...;

3) Попросите что-нибудь у Вашего соседа / преподавателя;

4) Поспорьте на предлагаемую тему;

5) Согласитесь с тем, что ... .

6) Продолжите высказывание ... (известного человека, русскую пословицу или поговорку и пр.)

Кроме языковых и коммуникативных упражнений, Битехтина и Климова предлагают использовать артикуляционные упражнения на самонаблюдение. Задания такого типа позволяют учащимся «прочувствовать» проблему: выявить артикуляционные позиции проблемных звуков, зафиксировать верное положение органов артикуляционного аппарата, дать кинемные характеристики фонем, что позволит осознать причины ошибок произношения. При выполнении упражнений для наблюдения за процессом артикуляции целесообразно использовать зеркало (фронтальную камеру телефона). К примеру, при работе с палатализованными / непалатализованными звуками авторы рекомендуют следующее задание: учащимся необходимо медленно, прислушиваясь к работе органов артикуляционного аппарата, произнести слова: «мат, мать, мят, мять; намок, намёк, намёки; лук, люк, люки; мэр, меры, мерить» (Битехтина, Климова, 2011, c. 24).

Далее учащимся следует ответить на вопросы: «как меняется качество гласных [a], [o], [y], [е] в зависимости от того, в соседстве с какими согласными (твердыми или мягкими) они находятся» (Битехтина, Климова, 2011, с. 24).

Помимо классических заданий, направленных на устранение фонетических трудностей начального этапа обучения, во время работы в моно- и полилинг- 
вальных группах нами активно использовались скороговорки, небольшие стихотворения и русские песни. Как известно, такие материалы прекрасно коррелируют друг с другом, способствуя общей цели - постановке и улучшению произношения, а также делают занятия «эмоционально насыщенными, развивая творческие способности, повышая мотивацию к изучению русского языка» (Черкес, 2016, с. 66). При работе с данным дидактическим материалом возможно использование одной и той же языковой единицы (с разными видами заданий) при коррекции нескольких фонетических проблем.

Обратимся к скороговоркам, которые уместно использовать при работе как в польскоязычной, так и в полилингвальной группе. Для подготовки заданий мы обращались к интернет-ресурсам (Скороговорки, http://skorogovor.ru/), а также использовали авторские материалы (последние отмечены знаком). Показала эффективные результаты следующая модель работы со скороговоркой (Красковская, 2015, с. 143):

1) преподаватель громко, с выразительной артикуляцией читает скороговорку и вводит новые лексические единицы;

2) учащиеся вслед за преподавателем медленно читают скороговорку, стараясь четко произнести каждый звук;

3) вместе с преподавателем студенты громко читают идиоматическое выражение (необходимо «прокричать» скороговорку 3-5 раз);

4) чтение скороговорки «шепотом», с четкой артикуляцией согласных звуков (3-5 раз)

5) индивидуальное чтение (эстафета: каждый читает по слову - потом по словосочетанию - и наконец, каждый учащийся читает скороговорку полностью).

Обычно к последнему этапу учащиеся уже знают текст наизусть. Кроме того, для снятия психологических и фонетических «зажимов» целесообразно использование гейм-технологий, поскольку «чрезмерная» концентрация внимания на «проблемных» звуках также может стать причиной фонетических неудач. Итак, во время работы над скороговоркой иногда полезно сыграть «в мяч»: предлагается поставить учащихся в круг или друг напротив друга, чтобы они бросали друг другу какой-нибудь предмет (мягкую игрушку, мяч), проговаривая скороговорку (см. задания п. 1-5).

Скороговорки, направленные на коррекцию звука [л], [л']:

Не мы ти на Ниле налима товили. Макака коалу в какао макала, коала какао тениво лакала. Вез корабль карамель, наскочил корабль на мель, моряки все три недели карамель на мели ели. Миллион тимонов для миллиона хамелеонов. Летом вечером в лесу подловил лесник лису*. Маленький Лёнька с Леной-малышкой вымыли мылом мышку и мишку*. Лола с Ларой, Лёля с Ликой в лес пошли за земляникой. Клара с Клавой и Мальвиной в сад залезли за малиной.

Скороговорки, способствующие исправлению произношения шипящих и свистящих звуков, а также устранению твердости звука $\left[\mathrm{ch} \neq\left[\mathrm{T}^{\prime} \mathrm{w}^{\prime}\right]\right.$ или замены его звуком [тс]: 
В час вечерний с чашкой чая паучок сверчка встречает. Два щенка, щека к щеке, щиплют щётку в уголке. Щёткой чищу я щенка, щекочу ему бока. Четьре чёрненьких чумазеньких чертёнка чертили чёрными чернилами чертёж. Черепаха, не скучая, час сидит за чашкой чая. Маша щёлкала щзипцами орешки*. Не шуршите, мылки, тише! Кочка Машка вас услышит ${ }^{*}$ Шура шустро сшила шубу из шиншиллью .

При работе с возвратными глаголами для устранения «позвукового» произношения постфиксов (такая фонетическая трудность имеется как в моно-, так и в полилингвальной группах), а также для отработки звука [тс] возможно использование следующих скороговорок:

Около колодиа кольио не найдётся. На софе так сладко спится, пусть девице прини приснится*. В изарстве молодеи, влюбился, на принцессе он женился*. В школу иыьпа собирался

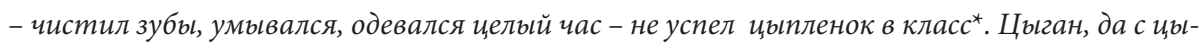
ганочкой Ганночкой, в столице таниуют «цызганочку»*.

К актуальной проблеме полилингвальной группы относится произношение звука [p] (в польскоязычной аудитории трудностью является [р']). Рекомендуемые скороговорки для коррекции проблем:

Розовые розы замерзают в морозы. Рыбак в реке словил ерша - уха сегодня хороша. Клара у Вари играет на рояле. У упрямого Прокопа урожай большой укропа. У пруда в траве во мраке перебились раки в драке. В гипермаркет приехала фура - привезла продавиам фурнитуру . Прохор прикупил продукты: помидоры, крупь, фрукты, рыбу, ипроты, огуреи... Ай да Прохор, молодеи.! Утром Рая для Кирилла три вареника сварила. Разбярился друг Кирилл - в бори вареник уронил. Прибежала рысь с рысёнком в регби поирать с тигрён$\kappa_{\text {ком }}^{*}$.

При работе над ритмикой, ударением, а также для отработки изучаемых интонационных конструкций русского языка рекомендуется учить со студентами стихотворения. Например, при изучении числительных предлагаются следующие небольшие по объему тексты:

Раз, два, три, четыре, пять,

Научились мы считать.

Ну а дальше мы не знаем,

Может, вместе посчитаем?

Шесть - конфеты любим есть,

Семь - мы помогаем всем,

Восемь - мьь друзей в беде не бросим.

Девять - учимся на пять,

Десять - кончили считать

(Считалки для детей https://deti-online.com/stihi/schitalki/)

Занимаюсь я отлично:

На четвёрки и пятёрки,

Потому что я читаю

Русские скороговорки.

Каждьй день я повторяю

Русские скороговорки!* 
12, 20, 19;

$17,10,46$;

$105,14,13$;

4, 8, 36 (Самойлова, Музыченко, Черкес, 2017, с. 57).

Известно, что песни являются прекрасным дидактическим материалом, потенциал которого позволяет корректировать фонетические ошибки учащихся. Песней, подходящей для фонетической работы как в моно-, так и в полиязычной группах, является прецедентное для русской культуры произведение Миллион алых роз. Данная песня обладает всеми необходимыми для учебного текста качествами: а) подходящим для отработки фонетических проблем звуковым составом: МиЛЛион, миЛЛион миЛЛион аЛых Роз... (Миллион алых роз); б) соответствием лексического состава и грамматических моделей уровню обучающихся; в) произносительной четкостью и ясностью; г) сюжетом, способным вызвать последующую дискуссию; д) социокультурным компонентом. На предтекстовом этапе работы с песней представляется прекрасная возможность познакомить универсантов с биографией грузинского художника Нико Пиросмани (1862-1918 гг.) / Николая Аслановича Пиросманашвили (Пиросманишвили) и его историей неразделенной любви к французской актрисе Маргарите де Сев (Черкес, 2017).

С текстом песни возможны такие варианты заданий (в зависимости от уровня группы и типа отрабатываемой фонетической проблемы):

1) подчеркните в тексте все слова, где присутствует указанный звук (звукосочетание, интонационная конструкиия (ИК));

2) усльшьте в песне знакомые слова и заполните пропуски;

3) запишите пропущенные словосочетания;

4) расставьте ударения в тексте песни.

Далее идут традиционные для работы с текстом этапы семантизации лексических единиц, фронтальное / индивидуальное чтение текста с сопутствующей коррекцией произносительных трудностей, коммуникативные задания: скажите... докажите... согласны ли $\mathrm{Bbl...} \mathrm{и,} \mathrm{наконец,} \mathrm{коллективное} \mathrm{исполнение}$ песни.

Для устранения влияния интерференции у польских студентов, отработки звуков [т'] и [тс] а также для развития слухопроизносительных навыков в полилингвальной группе при изучении числительных можно использовать детскую песню Дважды два четыре. Поскольку данная песня исполняется в достаточно быстром темпе, то для моно- и полиязычной групп задания будут дифференцированными: для польских студентов - расстановка ударений с последующим исполнением песни, а в интернациональной группе - аудирование, направленное на опознание в потоке звучащей речи пропущенных числительных.

Песня, которую можно использовать для устранения произносительных трудностей как в поли-, так и в монолигвальной группах - это детская колыбельная Спят усталые игрушки:

Спят устаЛые игруШки, книЖКи спят,

Одеяла и подуШки ждут ребят. 
Даже сказка спать ложиТСЯ,
Чтобы ночью нам присниТьСЯ.
Ты ей пожеЛай: «Баю-бай!»
В сказке можно покатаТьСЯ на луне
И по радуге промчаТьСЯ на коне.
Со сЛонёнком подружиТьСЯ
И поймать перо жар-птиЦь
Глазки закрывай! Баю-бай!...

(Спят усталье игрушки)

Также на начальном этапе и в процессе сопроводительного курса возможно использовать современную российскую песню группы «M-BAND» «Она вернется»:

Она вернёТСЯ, она вернёТСЯ;

Она мне ноЧью заменяеТ солнЦе.

Она услыШит, она заплаЧет;

И я наденуей кольЦо на пальЧик,

И я надену ей кольЦо на пальЧик.

(Она вернется)

При обращении к интернет-ресурсам можно найти специальные логопедические видеоупражнения, направленные на постановку звуков. Вот пример такого небольшого по объему, несложного по лексическому составу четверостишия-песни для отработки звука [p]. Сначала предлагается коллективно проговорить:

Рa-pa-pa-pa - вот высокая гора. Ро-ро-ро-ро - потерял петух перо. Ры-ры-ры-ры - за

горою комары. Ру-ру-ру-ру - а барсук унёс в нору.

(Детская Песня. Ра Ры Ро Ру Рэ. Потешка. Логоритмика. Развитие речи)

В качестве следующего этапа необходимо пропеть эту песню вместе в медленном темпе, четко артикулируя. Объем видео позволяет проговаривать и пропевать отрабатываемые звукосочетания и предложения как коллективно, так и по парам и, при необходимости, индивидуально.

Песней, которая на практике неоднократно показывала свою эффективность, является классическое музыкальное произведение группы «Машина времени» «Поворот». Несмотря на то, что преподавателю придется уделить несколько больше времени семантизации новых лексических единиц, при исполнении данной песни прекрасно отрабатывается звук [р]:

Вот новый повоРот и мотоР Ревёт, ито он нам несёт -

ПРопасть и взлёт, омут или бРод, и не РазбеРёшь, пока не повеРнёшь.

(Поворот)

Итак, при постановке русских звуков и коррекции произносительных проблем необходимо регулярно использовать как классические фонетические упражнения и аудитивные диктанты, направленные на развитие слухопроизносительных навыков универсантов, так и богатые возможности русской культуры - скороговорки, стихи и популярные песни. В гармоничном сочетании 
предлагаемые варианты заданий способствуют коррекции произношения универсантов, способствуют постепенному устранению фонетических проблем. Данный дидактический материал может использоваться на начальном этапе обучения РКИ, а также быть полезным как во время преподавания РКИ на продвинутом этапе, так и на краткосрочных языковых курсах.

\section{Библиография}

Anchimiuk, O. (2015). Обучение произношению сонорных [л], [л’] студентов-поляков. Linguodidactica, № 19. Online: https://core.ac.uk/download/pdf/83087875.pdf (27.02.2018).

Акишина, А. А., Каган, О. Е. (1997). Учимся учить. Москва: Русский язык.

Андреюшина, А. Е. (2014). Трудности освоения русской фонетики иноязычной аудиторией в зависимости от родного языка учащихся. Филологические науки. Bопросы теории и практики, № 12 (42). Online: http://scjournal.ru/articles/issn_1997-2911_2014_12-2_03.pdf (24.03.2018).

Битехтина, Н. Б., Климова, В. Н. (2011). Русский язык как иностранный: фонетика. Москва: Русский язык.

Валеева, Д., Шарафутдинова, О. (2017). Обучение арабов русской фонетике: перспективы использования электронной образовательной системы. Online: http://www.journals.vu.lt/ verbum/article/viewFile/11358/9822 (24.03.2018).

Еремина, В. В., Еремин, С. И. Овладение русской фонетикой: особенности работы с китайскими студентами на этапе довузовского обучения. Online: https://www.sworld.com.ua/index. $\mathrm{php} / \mathrm{ru}$ /pedagogy-psychology-and-sociology-411/theory-and-methods-of-studying-educationand-training-411/11180-411-0575 (25.03.2018).

Ибрагимова, Л. Г., Светлова, Р. М. (2016). Типы фонетических ошибок на начальном этапе обучения русскому языку как иностранному: опьы преподавания. Online: https://www.toptechnologies.ru/ru/article/view?id=35659 (25.03.2018).

Капитонова, Т. И., Московкин, Л. В. (2006). Методика обучения русскому языку как иностранному на этапе предвузовской подготовки. Санкт-Петербург: Златоуст.

Касько, Н. Н. (2000). Некоторые аспекты обучения небилологов русскому произнотению. Online: http://www.philol.msu.ru/ slavphil/books/jsk_12_19kasko.pdf (27.02.2018).

Красковская, И. Г. (2015). Караоке по-русски как один из приемов работы над фонетикой в иностранной аудитории. Studia Rossica Gedanensia. T. 2, с. 137-146.

Лингвистический энииклопедический словарь. Online: http://tapemark.narod.ru/les/197c.html (27.02.2018).

Любимова, Н. А. (1982). Обучение русскому произношению: артикуляция: постановка и коррекиия русских звуков. Москва: Русский язык.

Дергачева, Г. И. (ред.). (1983). Методика преподавания русского языка как иностранного на начальном этапе обучения. Москва: Русский язык.

Музыченко, Н. Г. (2014). Особенности обучения русскому как иностранному в мононациональных и полинациональных группах. Организационные аспекты обучения иностранньхх граждан: материаль Международной научно-практической конференции. Минск: РИВШ, с. 124-126.

Пархоменко, М. А. (2016). Работа над произношением на уровне A1 в аудитории франкофонов. Русский язык за рубежом. (Специальный выпуск). Online: https://journal-rla. pushkininstitute.ru/files/France.pdf (24.03.2018). 
Пассов, Е. И. (1989). Основы коммуникативной методики обучения иноязычному общению. Москва: Русский язык.

Власова, Н. С. (ред.). (1990). Практическая методика преподавания русского языка на начальном этапе. Москва: Русский язык.

Самойлова, И. Ю., Музыченко, Н. Г., Черкес, Т. В. (2017). Русский язык как иностранный: шаг первый: пособие. Гродно: ГрГУ им. Я. Купалы.

Сашина, А. С. (2016). Актуальные проблемы обучения студентов-иностранцев русскому произношению. Online: http://www.tsutmb.ru/nauka/internet-konferencii/2016/yazik-kulturaprof-comm/1/sashina.pdf (27.02.2018).

Трубецкой, Н. С. (1960). Основы фонологии. Москва: Издательство иностранной литературы.

Федянина, Н. А. (1979). Основные черты русской фонетики в сопоставлении с английской. Online: http://docplayer.ru/47818420-Osnovnye-cherty-russkoy-fonetiki-v-sopostavlenii-s-angliyskoy.html (24.03.2018).

Цзинь, Ш., Панова, Р. С. (2015). Фонетическая интерференция при произношении согласных в русской речи китайцев. Язык. Культура. Коммуникации, № 2. Online: http://journals.susu. $\mathrm{ru} / \mathrm{lcc} /$ article/view/102/282 (25.03.2018).

Черкес, Т. В. (2017). Мотивационно-ценностная роль песни на уроке РКИ. Методика преподавания иностранных языков и РКИ: традиции и инновации: сборник материалов II Международной научно-методической конференции-вебинара. Курск: ГБОУ ВПО КГМУ. Online: https://elib.grsu.by/doc/21776 (3.05.2018).

Черкес, Т. В. (2016). Скороговорки как средство коррекции трудностей произношения в иностранной аудитории. Вестник науки и образования, № 8 (20). Online: http://scienceproblems.ru/images/PDF/2016/8/VNO-8-20.pdf\#page=65 (1.05.2018).

\section{Электронные источники}

Детская песня: Ра Ры Ро Ру Рэ: потешка, логоритмика, развитие речи. Online: https://www. youtube.com/watch?v=NZiG8df_ik4 (01.05.2018).

Миллион алых роз. А. Вознесенский, муз. Р. Паулс. Online: <http://a-pesni.org/drugije/million. htm> (1.05.2018).

Она вернется. К. Меладзе, муз. К. Меладзе и А. Пиндюра. Online: https://www.gl5.ru/m/mband/m-band-ona-vernetsya.html (01.05.2018).

Поворот. А. Макаревич, муз. А. Кутиков. Online: https://www.gl5.ru/mashina-vremeni-povorot. html (01.05.2018).

Скороговорки. Online: http://skorogovor.ru/ (1.05.2018).

Спят усталье игрушки. Online: http://www.pesni.net/text/Detskie-pesni/Spyat-ustalye-igrushki> (01.05.2018).

Считалки для детей. Online: https://deti-online.com/stihi/schitalki/ (27.02.2018). 